\title{
Pharmacological inhibition of LSD1 for the treatment of MLL-rearranged leukemia
}

\author{
Zizhen Feng', Yuan Yao ${ }^{1}$, Chao Zhou', Fengju Chen², Fangrui Wu', Liping Wei', Wei Liư ${ }^{3,4}$, Shuo Dong', \\ Michele Redell ${ }^{3,4}$, Qianxing $\mathrm{Mo}^{2,5}$ and Yongcheng Song ${ }^{1,2^{*}}$
}

\begin{abstract}
Background: Mixed lineage leukemia (MLL) gene translocations are found in 75 \% infant and $10 \%$ adult acute leukemia, showing a poor prognosis. Lysine-specific demethylase 1 (LSD1) has recently been implicated to be a drug target for this subtype of leukemia. More studies using potent LSD1 inhibitors against MLL-rearranged leukemia are needed.

Methods: LSD1 inhibitors were examined for their biochemical and biological activities against LSD1 and MLL-rearranged leukemia as well as other cancer cells.

Results: Potent LSD1 inhibitors with biochemical $I_{50}$ values of 9.8-77 nM were found to strongly inhibit proliferation of MLL-rearranged leukemia cells with $\mathrm{EC}_{50}$ of 10-320 nM, while these compounds are generally non-cytotoxic to several other tumor cells. LSD1 inhibition increased histone H3 lysine 4 (H3K4) methylation, downregulated expression of several leukemia-relevant genes, induced apoptosis and differentiation, and inhibited self-renewal of stem-like leukemia cells. Moreover, LSD1 inhibitors worked synergistically with inhibition of DOT1L, a histone H3 lysine 79 (H3K79) methyltransferase, against MLL-rearranged leukemia. The most potent LSD1 inhibitor showed significant in vivo activity in a systemic mouse model of MLL-rearranged leukemia without overt toxicities. Mechanistically, LSD1 inhibitors caused significant upregulation of several pathways that promote hematopoietic differentiation and apoptosis.
\end{abstract}

Conclusions: LSD1 is a drug target for MLL-rearranged leukemia, and LSD1 inhibitors are potential therapeutics for the malignancy.

Keywords: MLL-rearranged leukemia, Lysine-specific demethylase 1, Enzyme inhibitor, Drug discovery, Leukemia therapeutics

\section{Background}

Acute leukemia, including acute lymphoblastic leukemia (ALL) and acute myeloid leukemia (AML), afflicts people of all ages, and it is the most common cancer affecting children under the age of 15 . Although certain subtypes of leukemia, e.g., childhood ALL, have achieved high cure rates, the 5-year survival rates for the majority of acute leukemia (mostly AML) patients are still low [1]. With a few exceptions, current treatments are conventional chemotherapeutics, which non-selectively

\footnotetext{
* Correspondence: ysong@bcm.edu

'Department of Pharmacology, Baylor College of Medicine, 1 Baylor Plaza, Houston, TX 77030, USA

${ }^{2}$ Dan L. Duncan Cancer Center, Baylor College of Medicine, 1 Baylor Plaza,

Houston, TX 77030, USA

Full list of author information is available at the end of the article
}

kill all rapidly proliferating cells including normal stem/ progenitor cells in the bone marrow and other organs (e.g., intestines). This causes severe toxicities and side effects, usually limiting the efficacy of these drugs. Biomarkers, such as mixed lineage leukemia (MLL) gene translocation and MEF2C [2], are frequently used to classify molecular subtypes of AML, predict prognosis, and determine therapeutic regimes. Acute leukemia carrying an MLL gene translocation accounts for the majority ( $\sim 75 \%$ ) of leukemia in infants as well as $\sim 10 \%$ in children and adults. This subtype of leukemia shows a poor prognosis, with 5 -year event-free survival being only $\sim 40 \%$ [3-5]. Intensified chemotherapy causes increased toxicity to patients without a significant 
improvement of survival. There is therefore a pressing need to find new therapeutics.

MLL is a large protein (3969 amino acid residues) with multiple domains (Additional file 1: Figure S1A and B). Its C-terminal SET domain, a homolog of Drosophila trithorax, is a histone H3 lysine 4 (H3K4) methyltransferase. The N-terminal AT hook domain recognizes the promoters or enhancers of certain genes and directs the methylation loci for the SET domain [6]. Studies show that methylated H3K4 (H3K4me1, 2, or 3) is associated with active transcription of many genes including Hox genes important for hematopoiesis [7, 8]. However, overexpression of certain Hox genes, such as HoxA9, leads to leukemogenesis [9]. Cellular H3K4 methylation is therefore tightly regulated. For example, MLL is assembled as a member of a large protein complex (with $\geq 29$ proteins) containing lysine-specific demethylase 1 (LSD1, also known as KDM1a) [10], which can demethylate H3K4me1 and 2 (but not H3K4me3) and plays an opposite role in keeping a balanced H3K4 methylation status [11] (Additional file 1: Figure S1B). In MLLrearranged leukemia, the onco-MLL loses the SET domain and is fused with one of the $>70$ documented genes (Additional file 1: Figure S1C), with AF4, AF10, AF9, and its homolog ENL being predominant (>70 \%) $[6,12]$. The mechanism for MLL leukemia has been well studied $[9,13,14]$. These MLL fusion partners are able to recruit DOT1L, a histone H3 lysine 79 (H3K79) methyltransferase (Additional file 1: Figure S1D). This leads to aberrant H3K79 methylation at MLL target gene loci, causing dysregulated gene expression (e.g., overexpression of HoxA9 and Meis1) and eventually initiation of the leukemia. Indeed, potent small molecule inhibitors of DOT1L, developed by us [15-17] and others [18-21], have been found to have selective activity against MLL leukemia.

LSD1 is a flavin adenine dinucleotide (FAD)-dependent monoamine oxidase (MAO), and its mechanism of catalysis is illustrated in Additional file 1: Figure S2 [11, 22]. The methyl group in H3K4me1 or 2 is removed by FAD-mediated oxidation, after which FAD is regenerated by oxidation with $\mathrm{O}_{2}$ to complete a catalytic cycle. The biological function of LSD1 is crucial, as LSD1 knockout in mice is embryonic lethal and conditional knockout blocked hematopoiesis [23]. Overexpression of LSD1 was found in several types of cancers (e.g., prostate and breast), suggesting that LSD1 might be a drug target for intervention [24-26]. Recently, LSD1 was reported to be required for leukemia stem cells (LSC) with MLL-AF9 fusion oncogene [27]. Using cyclopropylamine-based LSD1 inhibitors also showed in vitro and in vivo activity against MLL-AF9 leukemia. However, the compounds in the study exhibited severe toxicity, with many of the experimental mice dying of severe anemia/thrombocytopenia. More studies are therefore needed to show that this chemotype of LSD1 inhibitors can be safely used in the clinic [28, 29].

Here, we synthesized a series of cyclopropylaminebased LSD1 inhibitors and found that these compounds possess potent and selective activity against MLLrearranged leukemia, with their antileukemia activities correlated with LSD1 inhibitory activity. In addition, we show that one compound exhibited significant in vivo activity in a mouse model of MLL leukemia without obvious toxicities, showing that potent LSD1 inhibitors are potentially useful therapeutics for this subtype of acute leukemia. Molecular and cell biology studies were performed to characterize these compounds in MLLrearranged leukemia as well as possible mechanism(s) of action.

\section{Results}

LSD1 inhibitors exhibited potent antileukemia activity

A number of several chemotypes of LSD1 inhibitors have been reported [30-37], among which cyclopropylaminecontaining compounds exhibited low $\mathrm{nM} \mathrm{IC}_{50}$ values against the enzyme. However, these compounds have not been evaluated for their activity against leukemia cells. We synthesized compounds 1-3 (Fig. 1a) and tested their biochemical inhibition against recombinant human LSD1. Choosing these three compounds was based on their reported low nanometer inhibitory activity against LSD1 [30]. The LSD1 inhibition assay was performed with the reaction rate (i.e., amount of the product $\mathrm{H}_{2} \mathrm{O}_{2}$, Additional file 1: Figure S2) being quantitatively determined by adding horseradish peroxidase (HRP) and a HRP fluorescence substrate Amplex red. Thus, compound $\mathbf{1}$ with a flexible 4-benzyloxy group was found to be an extremely potent inhibitor with an $\mathrm{IC}_{50}$ value of $9.8 \mathrm{nM}$ (Table 1 ), which almost quantitatively deactivates LSD1 $(\sim 30 \mathrm{nM}$ in the assay). Compound 2 having a rigid fluoropyridine substituent is also a potent inhibitor with an $\mathrm{IC}_{50}$ of $77 \mathrm{nM}$. Compound 3 with a less bulky 4-Br group exhibited $2 \times$ more activity $\left(\mathrm{IC}_{50}=35 \mathrm{nM}\right)$ than 2 . These results are comparable to those reported previously [30].

Next, these three compounds were tested for their cellular activity against proliferation of MV4-11 leukemia cells bearing MLL-AF4 fusion oncogene. As representatively shown in Fig. 1b, unlike traditional chemotherapeutics that exhibit cytotoxicity within 2 days, the LSD1 inhibitors did not significantly affect proliferation of MV4-11 cells in a shorter period of time (e.g., 3 days), depending on their concentrations. However, upon incubation for $\geq 10$ days, these compounds showed potent activity against MV4-11 cells with $\mathrm{EC}_{50}$ values for compounds 1-3 being 10, 84 , and $20 \mathrm{nM}$, respectively (Table 1). The slow antiproliferative action suggests that these LSD1 inhibitors do not have general cytotoxicity, 
a<smiles>CN1CCN(C(=O)CNC2CC2c2ccc(OCc3ccccc3)cc2)CC1</smiles><smiles>CN1CCN(C(=O)CNC2CC2c2ccc(Br)cc2)CC1</smiles>

3

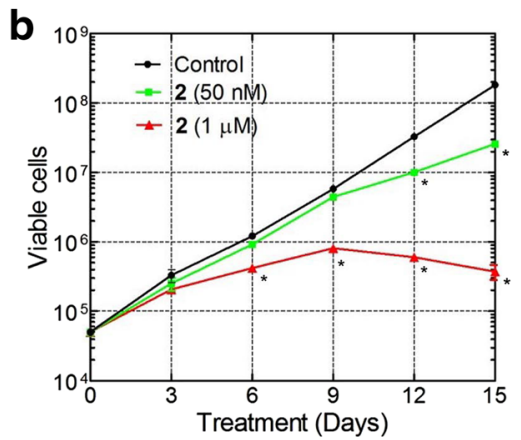

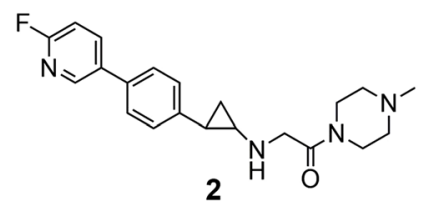<smiles>NCCc1ccc(-c2ccc(F)nc2)cc1</smiles>

4

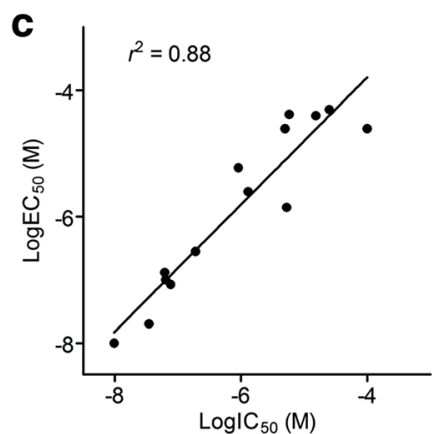

Fig. 1 LSD1 inhibitors blocked proliferation of MV4-11 leukemia cells. a Structures of compounds 1-4. b Growth curves for MV4-11 cells with or without treatment with compound $\mathbf{2}\left({ }^{*} p<0.01\right.$ with respect to the control). c Good correlation between enzyme IC 50 values of LSD 1 inhibitors and their antiproliferative activities, showing a $R^{2}$ of 0.88

e.g., inhibition of DNA/RNA/protein biosynthesis that affects all rapidly proliferating cells. Rather, similar to DOT1L inhibitors $[16,18]$, a series of cellular events are required for LSD1 inhibitors to inhibit cell growth, which could include blocked H3K4 demethylation, downregulation of leukemia-relevant genes, and depletion of downstream effector proteins.

\section{Antileukemia activity correlated with LSD1 inhibitory activity}

Given the potent activity of compounds 1-3, more analogous compounds were investigated. While detailed structure activity relationships of these compounds will be described in a separate publication, we show the antileukemia data of several representative compounds, including compound 4 (Fig. 1a), which is a fragment of compound 2 without the second substituent at the amine- $\mathrm{N}$ atom. Compound $\mathbf{4}$ exhibited a good inhibitory activity against $\mathrm{LSD} 1$ with an $\mathrm{IC}_{50}$ value of $5.3 \mu \mathrm{M}$ (Table 1), but it is $\sim 70$-fold less potent than compound 2 , showing the that the second substituent of 2 plays an important role in LSD1 inhibition. In addition, compound $\mathbf{4}$ was also found to have a significantly reduced antiproliferative activity $\left(\mathrm{EC}_{50}, 1.4 \mu \mathrm{M}\right)$ against MV4-11 leukemia cells.

Fourteen compounds (including compounds 1-4) with a broad range of LSD1 inhibitory activities with $\mathrm{IC}_{50}$ values of $9.8 \mathrm{nM}$ to $>100 \mu \mathrm{M}$ were selected and tested against proliferation of MV4-11 leukemia cells. The structures and biochemical $\mathrm{IC}_{50}$ values of compounds 5-14, as well as their antiproliferative $\mathrm{EC}_{50}$ values, are summarized in Additional file 1: Table S1. Overall, as shown in Fig. 1c, LSD1 inhibition (enzyme $\mathrm{IC}_{50}$ values) for these 14 compounds was found to be well correlated with their antiproliferation activity $\left(\mathrm{EC}_{50}\right.$ values), with the $R^{2}$ value of 0.88 . These results suggest that LSD1

Table 1 LSD1 inhibitory $\left(\mathrm{IC}_{50}, \mu \mathrm{M}\right)$ and antiproliferative (15-day treatment $\left.\mathrm{EC}_{50}, \mu \mathrm{M}\right)$ activities for compounds $\mathbf{1 - 4}$

\begin{tabular}{|c|c|c|c|c|c|c|c|}
\hline & \multirow{2}{*}{$\begin{array}{l}\text { LSD1 } \\
I_{50}\end{array}$} & \multicolumn{2}{|c|}{ MLL-rearranged leukemia } & \multicolumn{2}{|c|}{ Non-MLL leukemia cells } & \multirow{2}{*}{$\begin{array}{l}\text { Breast } \\
\text { MCF-7 }\end{array}$} & \multirow{2}{*}{$\begin{array}{l}\text { Prostate } \\
\text { LNCaP }\end{array}$} \\
\hline & & MV4-11 & Molm-13 & NB4 & U937 & & \\
\hline 1 & 0.0098 & 0.010 & 0.096 & 19.4 & 18.9 & 1.6 & 3.7 \\
\hline 2 & 0.077 & 0.084 & 0.32 & 18.9 & 34.6 & 6.6 & 10.0 \\
\hline 3 & 0.035 & 0.020 & 0.18 & $>50$ & $>50$ & 13.5 & 29.9 \\
\hline 4 & 5.3 & 1.4 & 12 & $>50$ & 17.5 & $>50$ & $>50$ \\
\hline
\end{tabular}


could be the cellular target responsible for the cell growth inhibition.

\section{Potent and selective activity against MLL-rearranged leukemia}

We next examined the spectrum of antitumor activity for compounds 1-4. These compounds were incubated with a panel of six human leukemia and solid tumor cell lines, including two MLL-rearranged leukemia cells MV4-11 and Molm-13 containing fusion oncogenes MLL-AF4 and -AF9, respectively. NB4 and U937 leukemia cells do not have an MLL translocation. Also included in the studies are breast cancer MCF-7 and prostate cancer LNCaP cells. Similar to their activities against MV4-11, compounds 1-4 had no or negligible activity against proliferation of all other tumor cells in a 3-day treatment. However, as summarized in Table 1, potent LSD1 inhibitors 1-3 showed particularly high activities against MLL-rearranged leukemia cells MV4-11 and Molm-13 with $\mathrm{EC}_{50}$ values of $10-320 \mathrm{nM}$. The cell activities seem to be in line with the LSD1 inhibitory activities, with compound $\mathbf{1}$ being the most potent $\left(\mathrm{EC}_{50}=10\right.$ and $96 \mathrm{nM}$ against MV4-11 and Molm-13). Moreover, less potent LSD1 inhibitor 4 was found to possess considerably reduced activities against the two MLL-rearranged leukemia cells $\left(\mathrm{EC}_{50}=1.4\right.$ and $\left.12 \mu \mathrm{M}\right)$.

NB4 and U937 leukemia cells without an MLL translocation exhibited low susceptibility to the treatment with compounds 1-3. The 15-day treatment $\mathrm{EC}_{50}$ values for compounds $\mathbf{1 - 3}$ are $\geq 19 \mu \mathrm{M}$, showing that these compounds have high selectivity ( $>108$-fold) against MLLrearranged leukemia cells. LSD1 has been reported to be overexpressed in breast and prostate cancers [24, 25]. The most potent LSD1 inhibitor 1 showed good antiproliferative activity against MCF-7 (breast) and LNCaP (prostate) cancer cells with 15-day $\mathrm{EC}_{50}$ values of 1.6 and $3.7 \mu \mathrm{M}$, respectively. Compound 2 had moderate activity (15-day $\mathrm{EC}_{50}, 6.6$ and $10 \mu \mathrm{M}$ ) against these two cells, while compound 3 did not significantly affect MCF-7 and LNCaP cells (15-day $\mathrm{EC}_{50}=13.5$ and $29.9 \mu \mathrm{M}$ ). These results show that MLL-rearranged MV4-11 and Molm-13 leukemia cells are far more sensitive to LSD1 inhibition.

\section{Activity against MAO-A/-B and selectivity for LSD1}

The cyclopropylamine LSD1 inhibitors were generally derived from $\mathrm{MAO}-\mathrm{A} / \mathrm{B}$ inhibitor tranylcypromine, an antidepression drug. Because MAO-A and - B play important roles in the degradation of neurotransmitters (e.g., serotonin and dopamine) in the central nervous system, selective inhibition for LSD1 is highly desirable. We tested compounds 1-4 for their biochemical activity against human MAO-A and $-\mathrm{B}$, and the results are summarized in Table 2. Compounds $\mathbf{1}$ and $\mathbf{2}$ exhibited only weak activity $\left(\mathrm{IC}_{50}, 17.5-480 \mu \mathrm{M}\right)$ against $\mathrm{MAO}-\mathrm{A}$ and $-\mathrm{B}$, showing
Table 2 Inhibitory activity $\left(\mathrm{IC}_{50}, \mu \mathrm{M}\right)$ against MAO-A and -B for compounds $\mathbf{1 - 4}$ and their selectivity indices for LSD1

\begin{tabular}{lllll}
\hline & LSD1 & MAO-A & MAO-B & Selectivity index \\
\hline 1 & 0.0098 & 17.5 & 34.2 & $>1700$ \\
2 & 0.077 & 120 & 480 & $>1500$ \\
3 & 0.035 & 7.3 & 16.3 & $>208$ \\
4 & 5.3 & 0.42 & 3.1 & $<0.58$ \\
\hline
\end{tabular}

excellent selectivity for LSD1 inhibition of $>1500$-folds. Compound 3 had moderate inhibitory activity $\left(\mathrm{IC}_{50}, 7.3\right.$ and $16.3 \mu \mathrm{M}$ ) against these two MAO enzymes and it also showed $>200 \times$ selectivity for LSD1. However, compound 4 without the second amine- $\mathrm{N}$ substituent exhibited more potent inhibitory activity against $\mathrm{MAO}-\mathrm{A}$ and $-\mathrm{B}\left(\mathrm{IC}_{50}\right.$, 0.42 and $3.1 \mu \mathrm{M}$, respectively). These results indicate that compounds $\mathbf{1}$ and $\mathbf{2}$ are highly potent and selective LSD1 inhibitors.

\section{Cell activities of LSD1 inhibitors}

Compounds $\mathbf{1}$ and $\mathbf{2}$ were selected for further biological activity testing. MV4-11 cells were treated with these two compounds for 3 days. Western blot experiments showed that both compounds $\mathbf{1}$ and $\mathbf{2}$ can increase cellular levels of H3K4me2 in a dose-dependent manner (Fig. 2a), indicating that these compounds are cell membrane permeable and inhibit LSD1 in MV4-11 cells. In addition, these compounds did not seem to consistently affect the global levels of H3K4me1 and H3K4me3. Other researchers observed the similar results using a different LSD1 inhibitor.

Next, we examined whether LSD1 inhibition can block the expression of HoxA9 and Meis1, whose overexpression has been observed in MLL-rearranged leukemia [9, 18, 20]. As shown in Fig. 2b, treatment with compounds $\mathbf{1}$ and $\mathbf{2}$ can significantly decrease the expression of both HoxA9 and Meis1 in a dosedependent manner.

Third, compounds $\mathbf{1}$ and $\mathbf{2}$ were found to be able to induce significant apoptosis of MV4-11 cells using fluorescence-activated cell sorting (FACS)-based Annexin$\mathrm{V}$ assay. As shown in Fig. 2c and Additional file 1: Figures S3 and S4, compound 1 at $30 \mathrm{nM}$ can induce $12 \%$ apoptosis on day 7 and showed an increased potency of $20 \%$ on day 14. At $300 \mathrm{nM}, 1$ exhibited more potent activity in inducing apoptosis of MV4-11, being $13 \%$ on day 7 and $26 \%$ on day 14 . Similarly, compound 2 at $0.1 \mu \mathrm{M}$ induced 11 and $13 \%$ apoptosis of MV4-11 cells in 7 and 14 days (respectively). It promoted significantly more apoptosis (45 and $49 \%$ for 7 and 14 days) at $1 \mu \mathrm{M}$. These results suggest that LSD1 inhibition led to an increased methylation at H3K4 and this epigenetic change suppressed the expression of leukemia relevant genes and induced apoptosis of MLL-rearranged leukemia cells. 

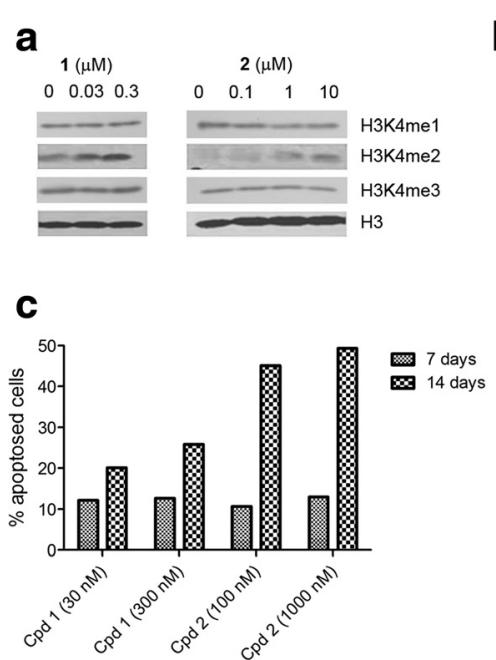

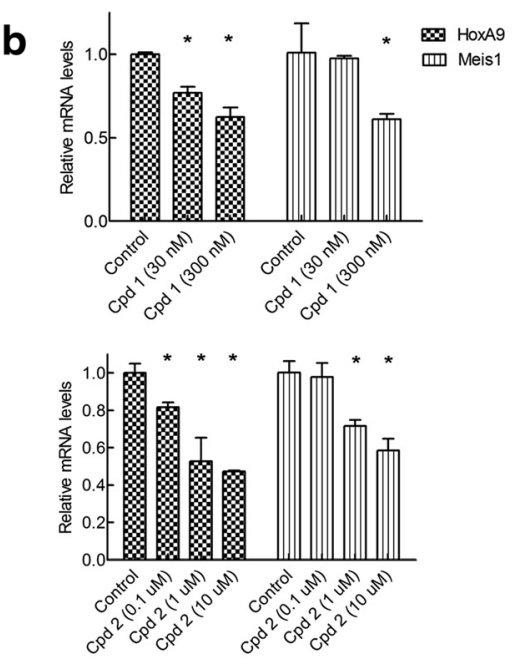

Fig. 2 Dose-dependent biological activities of compounds $\mathbf{1}$ and $\mathbf{2}$ in MV4-11 cells. a $\mathbf{1}$ and $\mathbf{2}$ caused increased levels of H3K4me2, while these compounds seem not to affect H3K4me1 and me3 significantly. b $\mathbf{1}$ (upper) and $\mathbf{2}$ (lower panel) reduced gene expression of HoxA9 and Meis1 whose overexpression is characteristic to MLL-rearranged leukemia ( ${ }^{*} p<0.05$ with respect to the control). $\mathbf{c} \mathbf{1}$ and $\mathbf{2}$ induced considerable amounts of apoptosis in 7 or 14 days

Studies have shown that there are a small proportion of stem-like cancer cells (also known as cancer stem cells) within the bulk of cancer, which possess certain traits of normal stem cells, e.g., self-renewal and ability to differentiate $[38,39]$. Importantly, only these stem-like cancer cells can form new tumors when transplanted into a new host, while the other non-stem cancer cells fail to do so. These stem-like cancer cells are more drug resistant and believed to be responsible for tumor metastasis and relapse. We found that LSD1 inhibition can induce differentiation of MV4-11 stem-like leukemia cells and inhibit cell migration. CD14 and CD11b are two cell surface proteins characteristic to differentiated macrophages/monocytes [18]. As shown in Fig. 3a, treatment with compounds $\mathbf{1}$ and 2 for 12 days caused significantly increased cells expressing high levels of CD14. Similarly, incubation with 2 led to considerably more CD11b ${ }^{+}$cells (Fig. $3 \mathrm{~b}$ ). These results indicate that LSD1 inhibition can induce differentiation of stem-like leukemia cells to become more matured macrophage-like cells. In addition, treatment with compound 2 for 4 days led to reduced ability for MV4-11 cells to migrate through a membrane with 8 - $\mu$ m pores (Fig. 3c), showing that LSD1 inhibition could have the potential to block tumor cell migration.

\section{LSD1 inhibition reduced colony-forming ability of human} primary MLL leukemia cells

Colony-forming assay using non-serum culture media represents a useful method to assess self-renewal capacity of stem-like cancer cells $[27,40]$. The number of cell colonies formed in the assay reflects the proportion of stem-like cells in a given number of cancer cells. To make the assessment more clinically relevant, we determined the ability of compounds 1-3 to inhibit the colony-forming ability of human primary leukemia cells from an AML patient with MLL-ENL fusion oncogene; $10^{4}$ primary leukemia cells were plated in Methocult H4434 methylcellulose medium containing increasing concentrations of compounds 1-3 and colonies in each culture dish were counted after 14 days. As shown in Fig. 3d, potent LSD1 inhibitors 1-3 were able to largely reduce the numbers of cell colonies with $\mathrm{EC}_{50}$ values of $0.43,0.52$, and $0.48 \mu \mathrm{M}$, respectively, showing that LSD1 inhibition can impair the leukemia stem-like cells in the clinical sample.

\section{Synergy when combined with DOT1L inhibition}

Previous biological studies have shown that H3K79 methyltransferase DOT1L is a drug target for MLLrearranged leukemia $[9,16,18]$. Medicinal chemistry by us and others has identified several highly potent DOT1L inhibitors [15-21]. SYC-522 (Additional file 1: Figure S5) is a potent and specific inhibitor of DOT1L with $K_{\mathrm{i}}$ of $0.5 \mathrm{nM}$ [16]. In our previous work, it can inhibit the H3K79 methylation in MV4-11 cells with an $\mathrm{IC}_{50}$ of $200 \mathrm{nM}$ [17]. SYC-522 also selectively blocked proliferation of MLL-rearranged leukemia cells, including MV4-11 and Molm-13 with the $\mathrm{EC}_{50}$ values of $\sim 4$ and $7 \mu \mathrm{M}[16]$.

We investigated the combination of LSD1 and DOT1L inhibition in MV4-11 and Molm-13 cells. These cells were treated with a matrix of increasing concentrations (from 0 to $0.1 \times, 0.33 \times, 1 \times, 3 \times$, and $10 \times \mathrm{EC}_{50}$ for each individual compound) of compound $\mathbf{1}$ (or 2) and SYC-522 
a
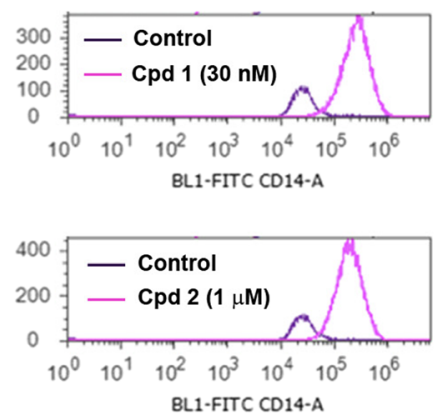

C

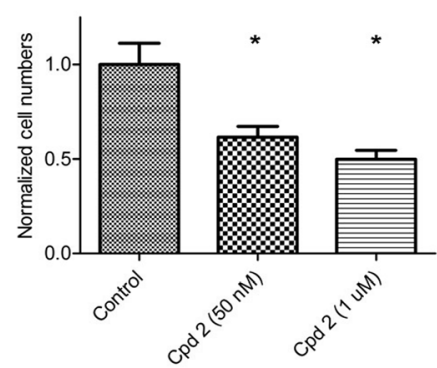

b
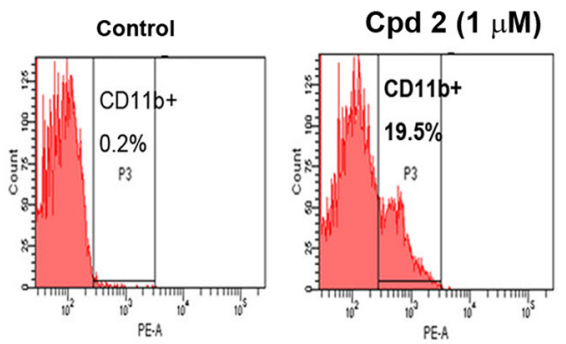

d

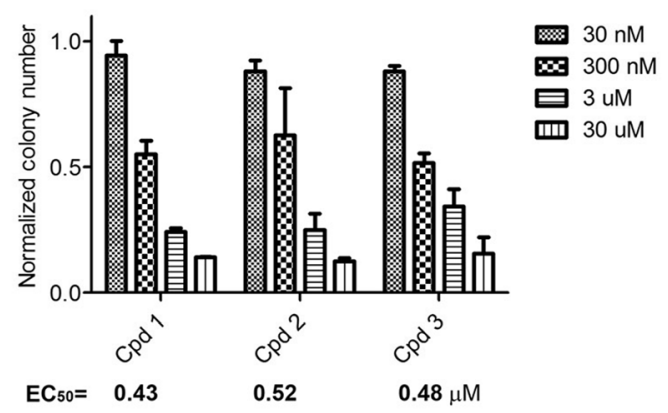

Fig. 3 LSD1 inhibition promoted differentiation and inhibited cell migration and self-renewal. a Treatment of MV4-11 cells with compounds $\mathbf{1}$ and $\mathbf{2}$ for 12 days caused $>90 \%$ cell populations expressing high levels of CD14, a cell surface protein characteristic for macrophages/monocytes. b Treatment of MV4-11 cells with 2 led to significantly more cells expressing high levels of CD11b, a cell surface protein for macrophages/monocytes. c Treatment with 2 significantly reduced numbers of MV4-11 cells that can migrate through a membrane with 8- $\mu m$ pores $\left(^{*} p<0.05\right.$ with respect to the control). $\mathbf{d}$ Treatment of human primary leukemia cells (from an MLL-rearranged leukemia patient) with LSD1 inhibitors $\mathbf{1 - 3}$ potently inhibited the colony-forming ability with $\mathrm{EC}_{50}$ values of $0.43,0.52$, and $0.48 \mu \mathrm{M}$, respectively

for 15 days. Cell viability in each well was determined and data were analyzed by the program CompuSyn, which calculates the combination index (CI) for each drug combination [41]. The combinations with $\mathrm{CI}<1$ indicate synergism for the two drugs, while those with $\mathrm{CI}=1$ show additive effect and those with $\mathrm{CI}>1$ represent antagonism. As shown in Fig. 4a, combinations of compounds 2 and SYC-522 exhibited strong synergy in inhibiting proliferation of MV4-11 cells, with the CI values ranging from 0.13 to 0.36 . Similarly, combinations of compounds 1 and SYC-522 also achieved strong synergy against Molm-13 cells (Fig. 4b). These results suggest that combination inhibition of these two enzymes can achieve synergism against this subtype of cancer.

\section{Compound 1 exhibited significant in vivo antileukemia activity without overt toxicity}

Given its very high cellular activity, compound $\mathbf{1}$ was tested for its in vivo antileukemia activity in a mouse model of MV4-11 leukemia. Previous in vivo pharmacokinetics studies of compound $\mathbf{1}$ showed that it is degraded rapidly in mice, having a short half-life $(\sim 1 \mathrm{~h})$ in the plasma [30]. Continuous infusion of $\mathbf{1}$ using a subcutaneously implanted osmotic pump was used for in vivo studies to avoid the unfavorable pharmacokinetics because this route may provide a stable plasma drug concentration. Compound $\mathbf{1}$ at 2.5 and $5 \mathrm{mg} / \mathrm{kg} /$ day for 28 days did not cause weight losses as well as any visible signs of toxicity in mice. Choosing 28-day drug administration was because of the slow antiproliferation activity of compound 1 . A blood test on day 28 showed no significant differences in blood cell counts as well as hemoglobin between mice in the treatment and control groups (Fig. 5a).

A mouse model of systemic MV4-11 leukemia was established by injecting $10^{7}$ MV4-11 cells/mouse intravenously through the tail veil into NOD-SCID mice with an engraftment rate of $100 \%$. After 2 weeks, human $\mathrm{CD}_{3} 3^{+} / \mathrm{CD} 45^{+}$leukemia cells $(0.1-0.5 \%)$ can be detected by FACS in blood samples of the mice. The disease progressed rapidly, causing deaths in $\sim 6$ weeks after leukemia transplantation. Thus, upon detection of MV411 engraftments, mice were randomly separated into treatment and control groups. Mice $(N=5)$ were treated with 1 using dosages of 2.5 and $5 \mathrm{mg} / \mathrm{kg} /$ day for 28 days, after which mice were sacrificed and their bone marrow, spleen, and blood were analyzed for human $\mathrm{CD}_{3} 3^{+} / \mathrm{CD} 45^{+}$leukemia cells. As shown in Fig. 5b, compound 1 was able to significantly inhibit the progression of the leukemia. The lower dose treatment 

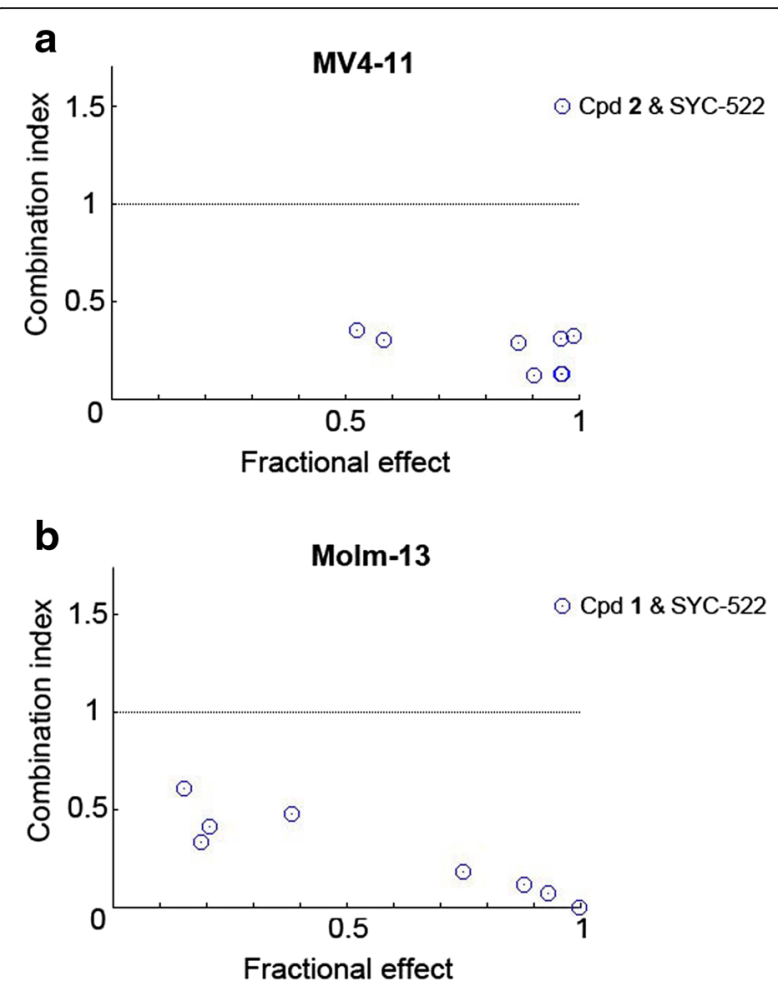

Fig. 4 Combination of LSD1 and DOT1L inhibition caused synergistic effects against proliferation of MLL-rearranged leukemia cells. a Combination treatment of MV4-11 cells with compounds $\mathbf{2}$ and SYC-522 exhibited combination index (CI) values of 0.13-0.36. b Combination treatment of Molm-13 cells with compounds 1 and SYC-522 showed combination index (Cl) values of $0.01-0.61$. Cl values $<1$ indicate synergism, while those $=1$ and $>1$ show additive effect and antagonism, respectively

reduced MV4-11 leukemia cells by $80 \%$ in the bone marrow (averaging $6.7 \%$ in the treatment vs. $33.6 \%$ in control group). Similarly, compound $\mathbf{1}$ caused 81 and $92 \%$ less leukemia cells in the spleen and blood, respectively. The antitumor effects were more pronounced in the higher dose treatment group, achieving 96, 89, and $99 \%$ inhibition rates in the bone marrow, spleen, and blood, respectively. In addition, large metastatic or invasive tumors in the gastrointestinal tract and ovaries were observed in the control mice, while none were visible in the treatment groups. In another set of antileukemia activity evaluation, survival experiments showed that compound 1 at the 2.5 and $5 \mathrm{mg} / \mathrm{kg}$ dosages can significantly prolong the lifespan of the leukemia-bearing mice $(p<0.05$, Fig. $5 c)$. The median survivals for the control and $2.5 \mathrm{mg} / \mathrm{kg}$ treatment group were 34.5 and 43 days, respectively. The higher dosage treatment caused an increased antitumor efficacy, with the median survivals for the two groups being 45 and 60 days, respectively. These results demonstrate that LSD1 inhibitors have significant in vivo antitumor activity and are potentially useful therapeutics for MLL-rearranged leukemia.

\section{Microarray studies of LSD1 inhibition}

Since methylated H3K4 is an important histone biomarker for gene regulation, we performed microarray studies to determine how potent and selective LSD1 inhibitors 1 and 2, which were found to increase H3K4me2, affect gene expression in MV4-11 leukemia cells. In addition, this profiling could help find the mechanism(s) by which these compounds inhibit proliferation, induce differentiation, and cause apoptosis of the leukemia cells.

To this end, triplicate samples of MV4-11 cells were treated with compounds $\mathbf{1}$ and $\mathbf{2}$ and the RNA of these samples was isolated, amplified, and hybridized to Illumina HT-12 microarrays. The microarray data were log2transformed and normalized to have the same median values for comparative analysis. Moderate $t$ test was applied to search for genes that were differentially expressed between the control and compound treated samples, using the filter thresholds of $p$ values $<0.05$ and fold changes $>4$. Compared to the untreated controls, compounds $\mathbf{1}$ and $\mathbf{2}$ were found to cause highly similar changes in gene expression pattern (Additional file 1: Figure S6) despite their different chemical structures, suggesting that LSD1, the common target of these two compounds, is responsible for the cellular activities. Next, we used gene set enrichment analysis (GSEA) in an effort to find the possible mechanism(s) for the LSD1 inhibition-mediated antileukemia activity. Expression of several gene sets/pathways related to hematopoietic differentiation as well as apoptosis was found to be significantly affected by LSD1 inhibition. As shown in Fig. 6a-c and Additional file 1: S7A-C, treatment with compounds $\mathbf{1}$ and $\mathbf{2}$ resulted in significant upregulation of the gene sets of hematopoietic cell lineage (HSA04640), leukocyte differentiation (GO:0002521), and hematopoietic or lymphoid organ development (GO:0048534), whose expression is important for the differentiation of hematopoietic stem or progenitor cells to become more matured lineages of blood cells as well as the development of hematopoietic organs. These results are consistent with our experimental observations showing that compounds $\mathbf{1}$ and $\mathbf{2}$ promoted considerable differentiation of MV4-11 cells. In addition, as shown in Fig. $6 \mathrm{~d}$ and Additional file 1: S7D, the two LSD1 inhibitors also caused significant upregulation of the pro-apoptotic gene set of regulation of programmed cell death (GO:0043067), which could lead to the observed increased apoptosis of MV4-11 cells upon treatment of these compounds.

\section{Discussion}

MLL translocations are found in $75 \%$ infant and $10 \%$ children/adult acute leukemia showing a poor prognosis, 

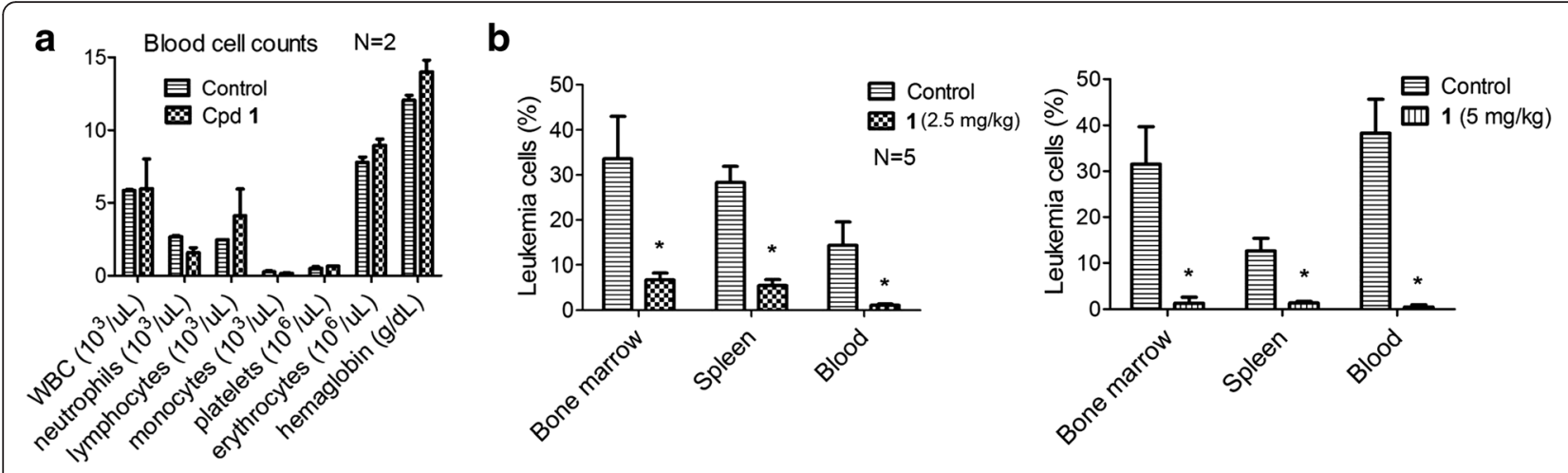

C
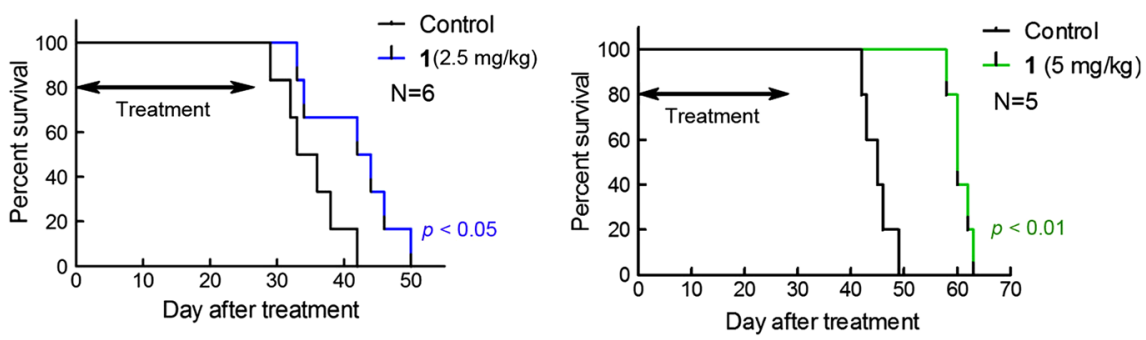

Fig. 5 In vivo activities of compound $\mathbf{1}$ in a systemic mouse model of MV4-11 leukemia. a Treatment of NOD-SCID mice with $\mathbf{1}$ caused no significant changes in blood cell counts, suggesting no obvious toxicities. b Compound $\mathbf{1}$ ( 2.5 and $5 \mathrm{mg} / \mathrm{kg} /$ day for 28 days) significantly reduced MV4-11 leukemia cells in the bone marrow, spleen, and peripheral blood, with the higher dosage showing more pronounced antitumor effects $\left({ }^{*} p<0.05\right.$ with respect to the control). c Treatment with $\mathbf{1}$ ( 2.5 and $5 \mathrm{mg} / \mathrm{kg} /$ day for 28 days) significantly prolonged the life span of mice transplanted with MV4-11 leukemia ( $p<0.05$ and 0.01 , respectively). The median survivals for the control and $2.5 \mathrm{mg} / \mathrm{kg}$ treatment group were 34.5 and 43 days, respectively. The higher dosage treatment caused an increased antitumor efficacy, with the median survivals for the two groups being 45 and 60 days, respectively

with 5 -year event-free survivals being $<40 \%[3-5]$. The phenotype of MLL-rearranged leukemias can be ALL, AML, or mixed lineage leukemia. However, despite the different phenotypes as well as the variety of fusion partner genes $(>70)$, this subtype of acute leukemias show a similar gene expression profile [42]. Therefore, MLL translocations can serve as a distinct biomarker in the clinic as well as for drug discovery and development [43]. There is a pressing need to find new drugs, especially less toxic therapeutics targeting onco-MLL, which loses the C-terminal SET domain that methylates H3K4. LSD1, which is able to demethylate H3K4me1 and 2, has been found in the MLL transcription complex and counteracts the SET domain of MLL. It is therefore assumed that MLL and LSD1 can keep a balanced methylation levels at H3K4, which is a critical "histone code" for active transcription [7, 8]. In MLL-rearranged leukemia, the balance in $\mathrm{H} 3 \mathrm{~K} 4$ methylation is impaired. In addition, studies have shown the majority of MLL fusion genes, including AF4, AF9, AF10, and ENL, can recruit DOT1L and methylate H3K79. This aberrant histone methylation at the MLL target gene loci causes overexpression of many Hox genes (e.g., HoxA7, HoxA9, and Meis1) that eventually cause leukemia initiation. More intriguing is that a recent report showed that the H3K4 methylation function of the wild-type MLL in the other allele is essential for MLL-rearranged leukemia [44]. It seems that the complicated "histone codes" at H3K4 and K79 in this malignancy need to be corrected. Pharmacological inhibition of DOT1L has been found to be an effective approach to the treatment of this subtype of leukemia, due to reduced H3K79 methylation levels that inhibit expression of the above leukemia relevant genes. A potent DOT1L inhibitor has been in clinical trials against MLL-rearranged leukemia [20]. More recently, LSD1 has been suggested to be a potential drug target for MLL-rearranged leukemia. However, as described in the "Background" section, more studies using potent and selective LSD1 inhibitors are needed to further validate this hypothesis.

In this work, a series of potent LSD1 inhibitors were synthesized and found to have very potent activity against proliferation of MLL-rearranged leukemia cells MV4-11 and Molm-13 with $\mathrm{EC}_{50}$ values of $10-320 \mathrm{nM}$, while these compounds had no or considerably weakened activity against proliferation of several other leukemia and solid tumor cells. Next, more medicinal chemistry studies showed that antileukemia activity of these compounds correlated with their LSD1 inhibitory activity, suggesting that LSD1 is the cellular target. Excellent LSD1 selectivity (200->1,000-folds) against related MAO-A and -B enzymes is also a desirable feature 
a

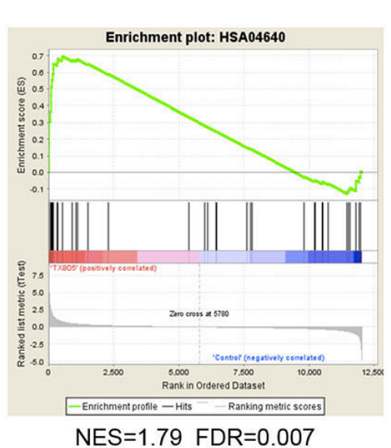

C

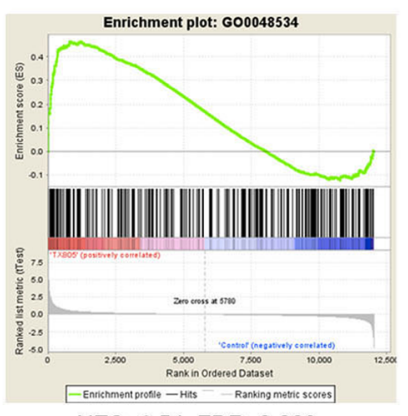

NES $=1.54$ FDR $=0.003$

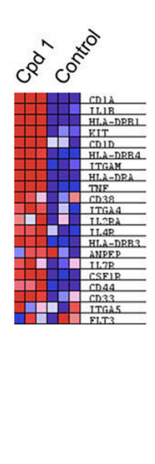

b

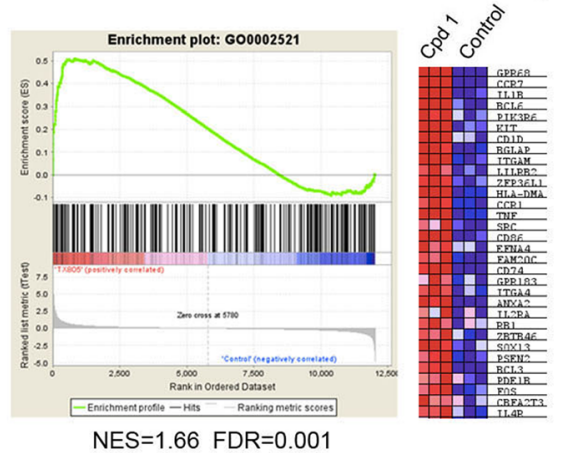

d

d
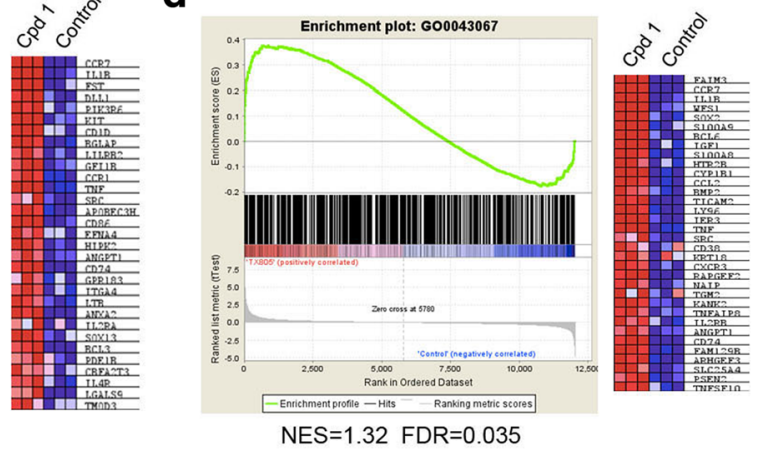

Fig. 6 Microarray results of LSD1 inhibition in MV4-11 cells. Upon treatment with compound $\mathbf{1}$ (100 nM), GSEA plots showed significant upregulation of the gene sets of a hematopoietic cell lineage (HSA04640), b leukocyte differentiation (GO:0002521), and c hematopoietic or lymphoid organ development (GO:0048534), as well as $\mathbf{d}$ the pro-apoptotic gene set of regulation of programmed cell death (GO:0043067). The right panels in a-d are heat maps showing expression levels of selected genes in the leading edges of the GSEA plots

of these compounds in the context of drug discovery. Two most potent LSD1 inhibitors $\mathbf{1}$ and $\mathbf{2}$ were found to be cell membrane permeable and can significantly increase the levels of H3K4me2 in MV4-11 cells. The most potent compound 1 showed significant antitumor activity in a systemic MV4-11 leukemia mouse model without overt toxicities to mice. Upon treatment $(5 \mathrm{mg} / \mathrm{kg})$, the leukemia burdens in the bone marrow, spleen, and peripheral blood were inhibited by $>89 \%$ and the life spans for the experimental animals were significantly prolonged, showing the potential of this class of compounds to become clinically useful therapeutics for MLL-rearranged leukemia.

More biological studies demonstrated that LSD1 inhibitors $\mathbf{1}$ and $\mathbf{2}$ were able to downregulate the expression of leukemia-relevant genes HoxA9 and Meis1, induce apoptosis, and differentiation. In addition, the ability of these compounds to inhibit colony-forming ability of primary MLL leukemia patient cells suggested that LSD1 inhibition impaired self-renewal of the stem-like leukemia cells. Microarray studies showed that LSD1 inhibition by compounds 1 and $\mathbf{2}$ caused significant upregulation of several gene sets that promote hematopoietic differentiation and apoptosis, which revealed the underlying mechanisms of LSD1 inhibition in MV4-11 leukemia cells.
Given the promising in vitro and in vivo antitumor activity, compound $\mathbf{1}$ represents a potential therapeutic agent against MLL-rearranged leukemia. MLL gene rearrangement could serve as a criterion for patient recruitment in a future clinical trial. More preclinical evaluation, especially animal pharmacokinetic studies, should be performed to further evaluate whether $\mathbf{1}$ as well as other LSD1 inhibitors are viable drug candidates. In addition, MLL translocations can also be found in a small portion $(<1 \%)$ of chronical myeloid leukemia (CML) patients [45]. Although rare, these patients had a low response rate to BCR-ABL inhibitor therapies and a poor prognosis. Evaluation of potent inhibitors of LSD1 (or DOT1L) against this molecular subtype of CML might be useful. It is also noted that LSD1 has been found to play a critical role in development [23]. Germline knockout of LSD1 is embryonically lethal. Conditional knockout in adult mice caused blocked hematopoiesis and pancytopenia. In addition to H3K4 and H3K9 [46] as well as other non-histone proteins such as DNMT1 (DNA methyltransferase 1) [47] are substrates of LSD1. For example, LSD1 is of importance to the stability, integrity, and function of DNMT1, an enzyme that maintains appropriate DNA methylation. LSD1 knockdown was found to cause global DNA hypomethylation [47]. 
These lines of evidence raise a safety concern of LSD1 inhibition. Nonetheless, another conditional LSD1 knockout mouse model study showed that after termination of LSD1 knockout, the impaired hematopoiesis can be fully recovered in the experimental animals [48]. Here, we further demonstrated that potent LSD1 inhibitor $\mathbf{1}$ can be safely administered ( $5 \mathrm{mg} / \mathrm{kg} /$ day) for an extended period of 28 days without overt toxicities to mice. Significant antitumor activity has also been observed. These experiments strongly suggest that there is a sufficient therapeutic window for pharmacological inhibition of LSD1 targeting leukemia.

Moreover, combination therapy could be a viable approach to further reduce the potential toxicity issue of LSD1 inhibitors. We show in this study that combination treatments of LSD1 inhibitors with a DOT1L inhibitor SYC-522 exhibited strong synergism against proliferation of MLLrearranged leukemia cells, presumably because H3K79 hypermethylation is closely associated with imbalanced H3K4 methylation in MLL-rearranged leukemia. In addition, since inhibition of LSD1 also caused DNA hypomethylation, the combination of an LSD1 inhibitor with a DNMT inhibitor (e.g., 5-azacitidine or decitabine) could also be effective.

\section{Conclusions}

LSD1 is a drug target for MLL-rearranged leukemia and small molecule LSD1 inhibitors are potential therapeutics for the malignancy.

\section{Methods}

\section{Cell lines and primary cells}

MLL-rearranged leukemia cells MV4-11 and Molm-13 were obtained from ATCC (American Type Culture Collection, Manassas, VA) and DSMZ (Deutsche Sammlung von Mikroorganismen und Zellkulturen $\mathrm{GmbH}$, Braunschweig, Germany), respectively. Non-MLL leukemia cells NB4 and U937 were described in our previous publications $[49,50]$. The primary samples were obtained from patients who were treated at Texas Children's Cancer Center and whose parents consented to the storage of remainder pheresis or bone marrow material for future research, in accordance with the IRBapproved protocol H-3342. The primary leukemia sample is the remainder bone marrow from a child diagnosed with AML with $t(11 ; 19)$.

\section{Compound synthesis and characterization}

All chemicals for synthesis were purchased from Alfa Aesar (Ward Hill, MA) or Aldrich (Milwaukee, WI). The compound identity was characterized by ${ }^{1} \mathrm{H}$ NMR on a Varian (Palo Alto, CA) 400-MR spectrometer. The purities of synthesized compounds were determined by a Shimadzu Prominence HPLC with a Zorbax C18 (or C8) column $(4.6 \times 250 \mathrm{~mm})$ monitored by UV at $254 \mathrm{~nm}$. The purities of the reported compounds were found to be $>95 \%$. Synthesis and characterization of compounds $\mathbf{1 - 4}$ can be found in Additional file 1.

\section{LSD1 enzyme inhibition}

Human LSD1 catalytic domain (172-833) was cloned and inserted into pGEX-KG vector. The correctness of insert was verified by sequencing. BL21-CodonPlus strain (Agilent) was transformed with the pGEX-KG-LSD1 plasmid and cultured at $37{ }^{\circ} \mathrm{C}$ in LB medium containing ampicillin $(50 \mu \mathrm{g} / \mathrm{mL})$ and chloramphenicol $(34 \mu \mathrm{g} / \mathrm{mL})$. Upon reaching an optical density of $\sim 0.9$ at $600 \mathrm{~nm}$, LSD1 expression was induced by adding $0.2 \mathrm{mM}$ isopropylthiogalactoside at $25{ }^{\circ} \mathrm{C}$ for $20 \mathrm{~h}$. Cells were harvested, lysed, and centrifuged at $20,000 \mathrm{rpm}$ for $20 \mathrm{~min}$, and the supernatant was collected and subjected to an affinity column chromatography using the glutathione sepharose resin. The GSTLSD1 fusion protein was eluted with $10 \mathrm{mM}$ of glutathione solution and purified by chromatography with a Superdex 200 gel filtration column with $\sim 90 \%$ purity (SDS-PAGE).

The inhibition assay for the recombinant LSD1 was performed using a published protocol [30], with the reaction rate (i.e., amount of the product $\mathrm{H}_{2} \mathrm{O}_{2}$ ) being quantitatively determined by adding HRP and a HRP fluorescence substrate Amplex red. In a 96-well microplate, an increasing concentration $(1 \mathrm{~nm}-100 \mu \mathrm{M})$ of an inhibitor was incubated with $30 \mathrm{nM}$ LSD1 in $50 \mathrm{mM}$ phosphate buffer $(\mathrm{pH}=7.0)$ containing $0.01 \%$ Brij-35 for $30 \mathrm{~min}$ at $25{ }^{\circ} \mathrm{C}$, before initiation of the reaction by adding $10 \mu \mathrm{M}$ of dimethylated peptide substrate ARTK $\left(\mathrm{Me}_{2}\right)$ QTARKSTGGKAPRKQKA $\left(\mathrm{K}_{\mathrm{m}} \sim 10 \mu \mathrm{M}\right)$. The total volume of the reaction mixture is $60 \mu \mathrm{L}$. After $20 \mathrm{~min}, 60-\mu \mathrm{L}$ solution containing HRP (0.01 unit) and Amplex red $(80 \mu \mathrm{M})$ was added and the fluorescence of each well was determined using a Beckman DTX880 microplate reader (excitation at 535 and emission at $595 \mathrm{~nm}$ ). Data were imported into Prism 5.0 (GraphPad), and the $\mathrm{IC}_{50}$ values were calculated by using the sigmoidal dose response curve fitting in the software. The reported $\mathrm{IC}_{50} \mathrm{~s}$ were the mean values of at least three independent experiments.

\section{Inhibition of MAO-A/-B}

Recombinant human MAO-A and - B were purchased from Sigma. The inhibitory activity was determined using MAO-Glo assay kit (Promega). In brief, following the manufacturer's protocol, assays were performed in 384-well white plates (Corning) using MAO-A or -B $(100 \mathrm{nM})$ with a final volume of $20 \mu \mathrm{L}$. Reactions were quenched after $60 \mathrm{~min}$ by adding reconstituted luciferin detection reagent $(20 \mu \mathrm{L} /$ well); $20 \mathrm{~min}$ after addition of the detection reagent, the luminescence of each well was measured using Beckman DTX-880 microplate reader. $\mathrm{IC}_{50}$ calculation was similar to that of LSD1. 


\section{Antiproliferation assay}

Proliferation inhibition assay for suspension leukemia cells was performed using an XTT assay kit (Roche) with our previously described method. Proliferation inhibition assay for solid tumor cell lines MCF-7 and LNCaP was performed using our previous described MTT assay. The antiproliferation $\mathrm{EC}_{50}$ values were determined by Prism, and the reported results were the mean values of at least three independent experiments.

\section{Western blot}

With increasing concentrations of a compound for 5 days, $10^{6}$ cells/well were incubated and histones extracted with the EpiQuik $^{\text {Tn }}$ Total Histone Extraction Kit (Epigentek) according to the manufacturer's protocol. Equal amounts of histones $(2 \mu \mathrm{g})$ were separated on SDS-PAGE and transferred to PVDF membranes. The blots were probed with H3K4-Me2 and H3 primary antibodies (Cell Signaling), followed by antirabbit IgG (Thermo Scientific) secondary antibodies.

\section{Flow cytometry}

For Annexin V apoptosis assay, $10^{5}$ cells/well were incubated with increasing concentrations of a compound for 7 or 14 days. Apoptosis was determined using the FITC Annexin V Apoptosis Detection Kit I (BD Bioscience) using the manufacturer's protocol. For other FACS assays, cells were labeled with fluorochrome-conjugated monoclonal antibodies against human CD14, CD11b, CD45, or CD33 (BD Biosciences) according to the manufacturer's recommendation. Cells were analyzed using a FACS Calibur (BD Biosciences/Applied Biosystems), and data were processed using the program Flowjo (version7.6.5).

\section{Quantitative real-time PCR}

For 3 days, $10^{4}$ cells/well were incubated with a compound, and the RNA was extracted from cells using RNeasy mini kit (QIAGEN); 100-1000 ng of total RNA was reverse transcribed using iScript ${ }^{\mathrm{tm}}$ Reverse Transcription Supermix (Bio-Rad) using the manufacturer's protocol. Quantitative real-time PCR was carried out using Fast SYBR Green Master Mix (Applied Biosystems) according to the manufacturer's instructions. Measurements were performed in triplicate, using GAPDH as the reference gene. Real-time PCR was performed using Biosystems Step One Plus detection system. The following sequences of primers are used:

HoxA9 (forward: 5'-AAAAGCGGTGCCCCTATACA3'; reverse: 5'-CGGTCCCTGGTGAGGTACAT-3');

Meis1 (forward: 5'-TGGCTGTTCCAGCATCTAACA CAC-3'; reverse: 5' -ACTGGTCTATCATGGGCTG CAC-3');

GAPDH (forward: 5'-GACAAAATGGTGAAGGTCGGTG3'; reverse: 5'-CTGGAACATGTAGACCATG-3')

\section{Colony-forming assay}

Human MLL-rearranged AML samples will be obtained from the Children's Oncology Group (COG) Biopathology Center, in accordance with the IRB-approved protocol H-24170. The colony-forming assay was performed according to our previously published method [40]. After 14 days, the colony number of each culture dish was counted and imported into Prism 5.0 and $\mathrm{EC}_{50}$ values were determined by using the sigmoidal dose response curve fitting in the software.

\section{Cell migration assays}

Cell migration assay was performed in a 24-well transwell plate with $8-\mu \mathrm{m}$ polyethylene terephthalate membrane filters (Falcon cell culture insert; Becton-Dickinson) separating the lower from the upper culture chambers, according to the manufacturer's instructions. In brief, MV4-11 cells were treated with or without compound 2 (50 nM and $1 \mu \mathrm{M})$ for 4 days. Triplicate samples of $10^{6}$ cells/well were plated in the upper chamber containing serum-free RPMI-1640. RPMI-1640 supplemented with $10 \%$ FBS in the bottom chamber was used to attract cells to move through the filter. Cells were allowed to incubate at $37^{\circ} \mathrm{C}$ for $4 \mathrm{~h}$, after which the cells that had migrated through the pores were harvested in the bottom chamber and counted. Results are presented as means \pm s.d.

\section{In vivo activity studies}

All of the mouse studies were conducted in strict compliance with the IRB-approved protocol. NOD-SCID mice (4 to 6 weeks old) were obtained from Jackson lab (Bar Harbor, ME, USA) and maintained under specific pathogen-free conditions; $10^{7}$ MV4-11 cells/mouse were injected intravenously through the tail veil, and animal weights were monitored twice a week. After 2 weeks when the blood samples showing $0.1-0.5 \%$ CD45+/CD33+ human leukemia cells, mice were randomly segregated into control and treatment groups. Mice in the treatment group were implanted subcutaneously in osmotic pumps (Alzet model 2004) containing $1.75 \mathrm{mg}$ of compound 1 in $200 \mu \mathrm{L}$ of PBS/DMSO (1:1). Animals were sacrificed when $>20 \%$ weight loss, hunched posture, ruffled fur, or inactivity was observed. The peripheral blood, spleen, and bone marrow cells were isolated and tested for $\mathrm{CD} 45^{+} / \mathrm{CD} 33^{+}$using FACS. Log-rank analysis was used to determine statistical significance of the survival curves using Prism 5.0.

\section{RNA amplification and microarray data analysis}

For 7 days, $10^{5}$ cells/well were incubated with compounds. Cells were treated with $\mathrm{Trizol}^{\circ}$ Reagent, frozen in liquid nitrogen, and shipped to Asuragen, Inc. (Austin, TX) for microarray experiments. RNA from these samples was isolated, amplified, and hybridized to Illumina Human 
HT-12 v4 arrays according to the manufacturer's protocol. Microarray data were $\log 2$ transformed and normalized to have the same median for all the arrays. Moderate $t$ statistics were used to find genes that were differentially expressed between the samples of interest. Benjamini and Hochberg method was used to correct for multiple comparisons. $\mathrm{R}$ and Bioconductor packages were applied for all the statistical analyses (see http://cran.us.r-project.org/, http://www.bioconductor.org/). GSEA analysis was performed using GSEA software from Broad Institute (Boston, MA).

\section{Additional file}

Additional file 1: Figures S1-S7, Table S1 and Compound synthesis and characterization. (PDF $1450 \mathrm{~kb}$ )

\section{Abbreviations}

AML: acute myeloid leukemia; ALL: acute lymphocytic leukemia; FACS: fluorescence-activated cell sorting; FAD: flavin adenine dinucleotide; H3K4: histone H3 lysine 4; H3K79: histone H3 lysine 79; LSD1: lysine specific demethylase 1; LSC: leukemia stem cells; MAO: monoamine oxidase; MLL: mixed lineage leukemia; PCM: (piperazin-1-yl)carbonylmethyl.

\section{Competing interests}

The authors declare that they have no competing interests.

\section{Authors' contributions}

ZF designed the experiments, performed most of the biological activity testing, analyzed data, and provided figures. YY did the antiproliferation assays and analyzed data. CZ and LW synthesized and characterized all compounds. FW performed the biochemical assays and analyzed data. WL and MR did the colony-forming assay of patient-derived samples. FC and QM performed the microarray data analysis and provided figures. SD performed the data analysis. YS conceived the project, designed the experiments, analyzed data, and wrote the manuscript. All authors read and approved the final manuscript.

\section{Acknowledgements}

This work was supported by a grant (RP150129) from Cancer Prevention and Research Institute of Texas (CPRIT) and a grant (R01NS080963) from NIH/ NINDS to Y.S. Flow cytometry was done in the Cytometry and Cell Sorting Core at Baylor College of Medicine with funding support from the $\mathrm{NIH}$ (Al036211, CA125123, and RR024574).

\section{Author details}

'Department of Pharmacology, Baylor College of Medicine, 1 Baylor Plaza, Houston, TX 77030, USA. ²Dan L. Duncan Cancer Center, Baylor College of Medicine, 1 Baylor Plaza, Houston, TX 77030, USA. ${ }^{3}$ Department of Pediatrics, Baylor College of Medicine, 1 Baylor Plaza, Houston, TX 77030, USA. ${ }^{4}$ Texas Children's Cancer and Hematology Centers, 1102 Bates Street, Houston, TX 77030, USA. ${ }^{5}$ Department of Medicine, Baylor College of Medicine, 1 Baylor Plaza, Houston, TX 77030, USA.

Received: 19 October 2015 Accepted: 2 March 2016

Published online: 12 March 2016

\section{References}

1. Leukemia Lymphoma Society database. http://www.lls.org/ \#/diseaseinformation/leukemia/. Accessed 18 Sept 2015.

2. Laszlo GS, Alonzo TA, Gudgeon CJ, Harrington KH, Kentsis A, Gerbing RB, et al. High expression of myocyte enhancer factor 2C (MEF2C) is associated with adverse-risk features and poor outcome in pediatric acute myeloid leukemia: a report from the Children's Oncology Group. J Hematol Oncol. 2015;8(1):115.
3. Chen CS, Sorensen PH, Domer PH, Reaman GH, Korsmeyer SJ, Heerema NA, et al. Molecular rearrangements on chromosome 11q23 predominate in infant acute lymphoblastic leukemia and are associated with specific biologic variables and poor outcome. Blood. 1993;81(9):2386-93.

4. Hilden JM, Dinndorf PA, Meerbaum SO, Sather H, Villaluna D, Heerema NA, et al. Analysis of prognostic factors of acute lymphoblastic leukemia in infants: report on CCG 1953 from the Children's Oncology Group. Blood. 2006:108(2):441-51.

5. Mrozek K, Heinonen K, Lawrence D, Carroll AJ, Koduru PR, Rao KW, et al. Adult patients with de novo acute myeloid leukemia and t(9; 11)(p22; q23) have a superior outcome to patients with other translocations involving band 11q23: a cancer and leukemia group B study. Blood. 1997:90(11):4532-8.

6. Krivtsov AV, Armstrong SA. MLL translocations, histone modifications and leukaemia stem-cell development. Nat Rev. 2007;7(11):823-33.

7. Briggs SD, Bryk M, Strahl BD, Cheung WL, Davie JK, Dent SY, et al. Histone H3 lysine 4 methylation is mediated by Set 1 and required for cell growth and rDNA silencing in Saccharomyces cerevisiae. Genes Dev. 2001;15(24):3286-95.

8. Milne TA, Briggs SD, Brock HW, Martin ME, Gibbs D, Allis CD, et al. MLL targets SET domain methyltransferase activity to Hox gene promoters. Mol Cell. 2002;10(5):1107-17.

9. Okada Y, Feng Q, Lin Y, Jiang Q, Li Y, Coffield VM, et al. hDOT1L links histone methylation to leukemogenesis. Cell. 2005;121(2):167-78.

10. Nakamura T, Mori T, Tada S, Krajewski W, Rozovskaia T, Wassell R, et al. ALL-1 is a histone methyltransferase that assembles a supercomplex of proteins involved in transcriptional regulation. Mol Cell. 2002;10(5):1119-28.

11. Shi Y, Lan F, Matson C, Mulligan P, Whetstine JR, Cole PA, et al. Histone demethylation mediated by the nuclear amine oxidase homolog LSD1. Cell. 2004;119(7):941-53.

12. Daser A, Rabbitts TH. The versatile mixed lineage leukaemia gene MLL and its many associations in leukaemogenesis. Semin Cancer Biol. 2005;15(3):175-88.

13. Bitoun E, Oliver PL, Davies KE. The mixed-lineage leukemia fusion partner AF4 stimulates RNA polymerase II transcriptional elongation and mediates coordinated chromatin remodeling. Hum Mol Genet. 2007;16(1):92-106.

14. Krivtsov AV, Feng Z, Lemieux ME, Faber J, Vempati S, Sinha AU, et al. H3K79 methylation profiles define murine and human MLL-AF4 leukemias. Cancer Cell. 2008;14(5):355-68.

15. Yao Y, Chen P, Diao J, Cheng G, Deng L, Anglin JL, et al. Selective inhibitors of histone methyltransferase DOT1L: design, synthesis, and crystallographic studies. J Am Chem Soc. 2011;133(42):16746-9.

16. Anglin JL, Deng L, Yao Y, Cai G, Liu Z, Jiang H, et al. Synthesis and structureactivity relationship investigation of adenosine-containing inhibitors of histone methyltransferase DOT1L. J Med Chem. 2012;55(18):8066-74.

17. Deng L, Zhang L, Yao Y, Wang C, Redell MS, Dong S, et al. Synthesis, activity and metabolic stability of non-ribose containing inhibitors of histone methyltransferase DOT1L. Med Chem Comm. 2013;4(5):822-6.

18. Daigle SR, Olhava EJ, Therkelsen CA, Majer CR, Sneeringer CJ, Song J, et al. Selective killing of mixed lineage leukemia cells by a potent small-molecule DOT1L inhibitor. Cancer Cell. 2011;20(1):53-65

19. Basavapathruni A, Jin L, Daigle SR, Majer CR, Therkelsen CA, Wigle TJ, et al, Conformational adaptation drives potent, selective and durable inhibition of the human protein methyltransferase DOT1L. Chem Biol Drug Des. 2012;80(6):971-80

20. Daigle SR, Olhava EJ, Therkelsen CA, Basavapathruni A, Jin L, Boriack-Sjodin PA, et al. Potent inhibition of DOT1L as treatment of MLL-fusion leukemia. Blood. 2013;122(6):1017-25.

21. Yu W, Chory EJ, Wernimont AK, Tempel W, Scopton A, Federation A, et al. Catalytic site remodelling of the DOT1L methyltransferase by selective inhibitors. Nat Commun. 2012;3:1288.

22. Binda C, Valente S, Romanenghi M, Pilotto S, Cirilli R, Karytinos A, et al. Biochemical, structural, and biological evaluation of tranylcypromine derivatives as inhibitors of histone demethylases LSD1 and LSD2. J Am Chem Soc. 2010;132(19):6827-33.

23. Kerenyi MA, Shao Z, Hsu YJ, Guo G, Luc S, O'Brien K, et al. Histone demethylase Lsd1 represses hematopoietic stem and progenitor cell signatures during blood cell maturation. eLife. 2013;2:e00633.

24. Kahl P, Gullotti L, Heukamp LC, Wolf S, Friedrichs N, Vorreuther R, et al. Androgen receptor coactivators lysine-specific histone demethylase 1 and four and a half LIM domain protein 2 predict risk of prostate cancer recurrence. Cancer Res. 2006;66(23):11341-7. 
25. Lim S, Janzer A, Becker A, Zimmer A, Schule R, Buettner R, et al. Lysine-specific demethylase 1 (LSD1) is highly expressed in ER-negative breast cancers and a biomarker predicting aggressive biology. Carcinogenesis. 2010;31(3):512-20.

26. Schulte JH, Lim S, Schramm A, Friedrichs N, Koster J, Versteeg R, et al. Lysine-specific demethylase 1 is strongly expressed in poorly differentiated neuroblastoma: implications for therapy. Cancer Res. 2009;69(5):2065-71.

27. Harris WJ, Huang X, Lynch JT, Spencer GJ, Hitchin JR, Li Y, et al. The histone demethylase KDM1A sustains the oncogenic potential of MLL-AF9 leukemia stem cells. Cancer Cell. 2012;21(4):473-87.

28. Dent SY, Chandra J. The lasting influence of LSD1 in the blood. eLife. 2013;2:e00963.

29. Lynch JT, Harris WJ, Somervaille TC. LSD1 inhibition: a therapeutic strategy in cancer? Expert Opin Ther Targets. 2012;16(12):1239-49.

30. Neelamegam R, Rica EL, Malvaez M, Patnaik D, Norton S, Carlin SM, et al. Brain-penetrant LSD1 inhibitors can block memory consolidation. ACS Chem Neurosci. 2012;3(2):120-8.

31. Sorna V, Theisen ER, Stephens B, Warner SL, Bearss DJ, Vankayalapati H, et al. High-throughput virtual screening identifies novel N'-(1-phenylethylidene)benzohydrazides as potent, specific, and reversible LSD1 inhibitors. J Med Chem. 2013:56(23):9496-508.

32. Suzuki T, Miyata N. Lysine demethylases inhibitors. J Med Chem. 2011; 54(24):8236-50.

33. Zheng YC, Duan YC, Ma JL, Xu RM, Zi X, Lv WL, et al. Triazoledithiocarbamate based selective lysine specific demethylase 1 (LSD1) inactivators inhibit gastric cancer cell growth, invasion, and migration. J Med Chem. 2013;56(21):8543-60.

34. Fiskus W, Sharma S, Shah B, Portier BP, Devaraj SG, Liu K, et al. Highly effective combination of LSD1 (KDM1A) antagonist and pan-histone deacetylase inhibitor against human AML cells. Leukemia. 2014;28(11):2155-64.

35. Prusevich P, Kalin JH, Ming SA, Basso M, Givens J, Li X, et al. A selective phenelzine analogue inhibitor of histone demethylase LSD1. ACS Chem Biol. 2014;9(6):1284-93.

36. Huang Y, Greene E, Murray Stewart T, Goodwin AC, Baylin SB, Woster PM, et al. Inhibition of lysine-specific demethylase 1 by polyamine analogues results in reexpression of aberrantly silenced genes. Proc Natl Acad Sci U S A. 2007;104(19):8023-8

37. Sharma SK, Wu Y, Steinbergs N, Crowley ML, Hanson AS, Casero RA, et al. (Bis)urea and (bis)thiourea inhibitors of lysine-specific demethylase 1 as epigenetic modulators. J Med Chem. 2010;53(14):5197-212.

38. Lapidot T, Sirard C, Vormoor J, Murdoch B, Hoang T, Caceres-Cortes J, et al, A cell initiating human acute myeloid leukaemia after transplantation into SCID mice. Nature. 1994;367(6464):645-8.

39. Misaghian N, Ligresti G, Steelman LS, Bertrand FE, Basecke J, Libra M, et al. Targeting the leukemic stem cell: the Holy Grail of leukemia therapy. Leukemia. 2009;23(1):25-42.

40. Liu W, Deng L, Song Y, Redell M. DOT1L inhibition sensitizes MLLrearranged AML to chemotherapy. PLoS One. 2014;9(5):e98270.

41. Chou TC. Theoretical basis, experimental design, and computerized simulation of synergism and antagonism in drug combination studies. Pharmacol Rev. 2006;58(3):621-81.

42. Ross ME, Mahfouz R, Onciu M, Liu H-C, Zhou X, Song G, et al. Gene expression profiling of pediatric acute myelogenous leukemia. Blood. 2004:104(12):3679-87.

43. Smith AD, Roda D, Yap TA. Strategies for modern biomarker and drug development in oncology. J Hematol Oncol. 2014:7:70

44. Thiel AT, Blessington P, Zou T, Feather D, Wu X, Yan J, et al. MLL-AF9-induced leukemogenesis requires coexpression of the wild-type MII allele. Cancer Cell. 2010;17(2):148-59.

45. Wang W, Tang G, Cortes JE, Liu H, Ai D, Yin CC, et al. Chromosomal rearrangement involving 11q23 locus in chronic myelogenous leukemia: a rare phenomenon frequently associated with disease progression and poor prognosis. J Hematol Oncol. 2015;8:32.

46. Metzger E, Wissmann M, Yin N, Muller JM, Schneider R, Peters AH, et al. LSD1 demethylates repressive histone marks to promote androgenreceptor-dependent transcription. Nature. 2005;437(7057):436-9

47. Wang J, Hevi S, Kurash JK, Lei H, Gay F, Bajko J, et al. The lysine demethylase LSD1 (KDM1) is required for maintenance of global DNA methylation. Nat Genet. 2009:41(1):125-9.
48. Sprussel A, Schulte JH, Weber S, Necke M, Handschke K, Thor T, et al. Lysine-specific demethylase 1 restricts hematopoietic progenitor proliferation and is essential for terminal differentiation. Leukemia. 2012;26(9):2039-51.

49. Jiang X, Sun L, Qiu JJ, Sun X, Li S, Wang X, et al. A novel application of furazolidone: anti-leukemic activity in acute myeloid leukemia. PLoS One. 2013;8(8):e72335.

50. Zeisig BB, Kwok C, Zelent A, Shankaranarayanan P, Gronemeyer H, Dong S, et al. Recruitment of RXR by homotetrameric RARalpha fusion proteins is essential for transformation. Cancer Cell. 2007;12(1):36-51.

\section{Submit your next manuscript to BioMed Central and we will help you at every step:}

- We accept pre-submission inquiries

- Our selector tool helps you to find the most relevant journal

- We provide round the clock customer support

- Convenient online submission

- Thorough peer review

- Inclusion in PubMed and all major indexing services

- Maximum visibility for your research

Submit your manuscript at www.biomedcentral.com/submit
Biomed Central 